\title{
Maritime Certainty and International Cooperation in the Klondike and Alaska Gold Rushes, 1896-1903
}

\section{Preston Jones}

At the end of the nineteenth century the Arctic was a region of potential conflict. A primary cause of conflict is uncertainty. In the Arctic and near Arctic during the Klondike and Nome gold rushes, a degree of certainty came from two key sources: predictable US shipping and widely-respected Canadian law enforcement. A common culture among many newcomers to the region played an important role but, drawing on Abraham Maslow's well-known "hierarchy of needs" theory, this paper argues that generally reliable shipping and generally respected law enforcement laid the foundation for a culture of cooperation described in numerous gold rush memoirs.

À la fin du $19^{e}$ siècle, l'Arctique était une région de conflits potentiels. L'incertitude constitue l'une des principales causes des conflits. Dans l'Arctique et les régions voisines de l'Arctique pendant les ruées vers le Klondike et Nome, un certain degré de certitude provenait de deux sources clés: la prévisibilité du transport maritime américain et le grand respect accordé à l'application de la loi au Canada. Bien que la culture commune à bon nombre des nouveaux arrivants dans la région ait joué un grand rôle, l'auteur s'appuie sur la théorie bien connue de la " hiérarchie des besoins" d'Abraham Maslow pour soutenir qu'un transport généralement fiable et une application de la loi généralement respectée ont jeté les bases d'une culture de collaboration décrite dans plusieurs mémoires de la ruée vers l'or.

The Northern Mariner / Le marin du nord 31, no. 1 (Spring 2021): 61-78 


\section{Introduction}

In the early decades of the twenty-first century the Arctic has become a zone of commercial and military competition. A 2019 United States Coast Guard review noted that access to the Arctic's "vast energy, mineral, fisheries and other commercial resources" were at stake, while various reports have highlighted growing competition and tensions in the region, spurred on by climate change and the melting ice. ${ }^{1}$ The US government characterizes Russia as a "near competitor" in the region, though Russia actually appears to possess Arctic dominance and views eminence in the polar region as a key to restoring its status as a world power. ${ }^{2}$ China, meanwhile, calls itself a "near-Arctic State" and has launched repeated expeditions to the region. Discussions of the situation in the Arctic have compared it to long-brewing international strains in the South China Sea. ${ }^{3}$

Underpinning international anxiety about the situation in the Arctic is uncertainty, a primary cause of conflict within and among individuals and societies. The ancient Greek historian Thucydides famously observed that the growth of military power in Athens and the fear - or the uncertainty - this stoked in Sparta made war inevitable. ${ }^{4}$ The foundational seventeenth-century political philosopher Thomas Hobbes located the basic causes of conflict in competition, mistrust, and the pursuit of glory at the expense of others, an underlying problem being uncertainty. The naval theorist Alfred Thayer Mahan noted in his best-known work, published just a few years before the Klondike gold rush, that wars were triggered by a "clash of interests" and "feelings roused by conflicting attempts ... to appropriate the larger share of ... the advantages of commerce." In other words, hostility fed by mistrust and uncertainty.

The United States' definition of the Arctic includes Alaska's Aleutian Islands, the Seward Peninsula, and the northern third of Canada's Yukon Territory. ${ }^{6}$ If, for the sake of discussion, we accept that definition, and if we turn the time dial back 120 years, we will obviously find profound differences - e.g. no cars or fresh

1 US Coast Guard, Arctic Strategic Outlook (Washington, DC: Government Printing Office, 2019), 2, 3; and Michael M. Phillips and James Marsen, "Russia's Neighbors Rebuild Defenses," Wall Street Journal, 6 January 2021, A8.

2 Matthew Melino and Heather A. Conley, "The Ice Curtain: Russia's Arctic Military Presence," Center for Strategic \& International Studies, 26 March 2020, https://www.csis.org/features/icecurtain-russias-arctic-military-presence.

3 See, for example, Jean-Michel Bazatt, "Arctique: Poutine ne perd pas le Nord," Le Monde, 11 February 2017, https://www.lemonde.fr/idees/article/2017/02/11/arctique-poutine-ne-perd-pas-lenord $5078171 \quad 3232 . \mathrm{html}$.

$4 \quad$ Paul Kennedy, The Rise and Fall of the Great Powers: Economic Change and Military Conflict from 1500 to 2000 (New York: Random House, 1987), 198.

5 Alfred Thayer Mahan, The Influence of Sea Power upon History, 1660-1783 (New York Dover Publications, 1987 [ repr. 1894]), 1.

6 In part, "all United States [and] foreign territory north of the Artic Circle and all United States territory north and west of the boundary formed by the Porcupine, Yukon and Kuskokwim Rivers." In US Coast Guard, Arctic Strategic Outlook, 11. 
tropical fruit in the middle of winter. But we will also find similarities. In 1898 as in the 2020s, the natural resources of the Arctic and near Arctic - at that time, chiefly gold - attracted international attention. In 1898 as in the 2020s, powers of varying strengths - at that time, Britain, Canada, and the United States - coveted these resources.

At the time of writing, responses to uncertainty in the Arctic and the consequences of those responses have yet to unfold. In some respects, history can inform action, for the tensions of the latter 1890s were resolved and led to an era in the Arctic and near Arctic of remarkable cooperation. This cooperation was rooted in a sense of certainty, or as much certainty as could be had at that historical moment in a region so harsh and distant from large population centers. From certainty sprang security. And from security sprang the possibility of goodwill and cooperation in an international context.

The central argument of this paper is that a culture of cooperation that existed along the waterways and trails from Skagway and Dyea (in Alaska) to Dawson City (in Canada), and from Dawson to St. Michael and Nome (in Alaska) during the Klondike and Alaska gold rushes rested on two posts of certainty: the predictability of mostly American shipping and the competence of mostly Canadian policing. ${ }^{7}$ The more basically important of the two was shipping, for law enforcement relied on it as much as everyone else. Together, the posts of shipping and policing comprised an infrastructure of psychological security upon which stampeders and others in the region could build an international culture of cooperation. ${ }^{8}$

\section{Geopolitical and Regional Challenges}

If a general culture of cooperation existed in Alaska and the Yukon Territory during the gold rushes, this reflected a degree of harmony at a higher, geopolitical level. Initially, it seems strange to speak of cooperation between Britain and the US in the latter nineteenth century. In 1895 there had been talk of war between

\footnotetext{
7 A thoughtful anonymous reviewer of a draft of this paper wrote: "I disagree with the central argument that the culture of cooperation in the far northwest was built on certainty and stability. To me, cooperation was built on a lack of certainty and stability/security. Because there was uncertainty on the location of the international border and the reliability of shipping routes etc., Americans, Canadians, and others had to cooperate to succeed in the region. Certainly the result of their cooperation was reliable shipping and competent policing, but I wouldn't say that the level of certainty and stability the article describes existed until 1900 at the earliest. I would suggest thinking of certainty and stability as more of a process during the period under discussion. Rather than certainty and stability leading to cooperation, cooperation leading to certainty and stability." As seen below, the present writer draws on Abraham Maslow's "hierarchy of needs" to suggest that amicable cooperation is predicated on a degree of stability and certainty insofar as life's most basic needs are concerned. It is not certain that the disagreement is great and may be a matter of emphasis and nuance.

8 See Douglas W. Allen, "Information Sharing during the Klondike Gold Rush," Journal of Economic History LXVII, no. 4 (December 2007): 944-967. Allen also sees a culture of trust in the Klondike and attributes it to the work of the Canadian North-West Mounted Police creating a sense of security among miners who were confident their own claims would be protected.
} 
the two countries as a result of a dispute involving the border of Venezuela and British Guiana. At the time of the Klondike gold rush, Canada's governor general, Lord Minto, wrote of an "undercurrent of hatred" for the British among Americans, especially among Irish and German immigrants. Minto worried about the possibility of Irish nationalist raids into Canada from the US, as there had been after the American Civil War. He expressed concern about the indefensibility of Vancouver and Winnipeg in the event of an American invasion. ${ }^{9}$

For a brief time, it seemed that tensions between Canada and the US in the far northwest might lead to conflict. There were minor incidents, such as when men in Skagway plucked a British flag from a Canadian establishment and stomped it in the mud. ${ }^{10}$ The event was reported nationally but any fever attached to it quickly passed. This episode was linked to the contentious question about the boundary between Alaska and British Columbia. That issue had lurked since the US purchase of Alaska from Russia in $1867,{ }^{11}$ but now that it was tied to sea access to the gold fields of the Yukon Territory, the border became, in Lord Minto's words, a topic of "vast importance." 12 He wondered if tensions in the boundary region would simmer and lead to "dangerous friction" between the North American nations, and thus between the US and Britain. He recorded Prime Minister Wilfrid Laurier's concern that the "grave" border matter in the far northwest could "lead to bloodshed." 13 The American observer John Dos Passos noted Laurier's concern about the possibility of "a disgraceful conflict" which could be triggered if gold were discovered in the disputed boundary region. ${ }^{14}$

In the end, the boundary decision favored the US and left sea access to the gold field routes in American hands. The historical consensus is that the US had the stronger argument. ${ }^{15}$ But even if it had not, the American argument probably would have been favored because the decision came amidst an era of rapprochement between Britain and the United States. In quick order from the mid-1890s, Britain made formal and informal concessions to the US in relation to the VenezuelaGuiana border, Hawaii, the Philippines, and the Isthmus of Panama. Facing an empire-full of problems and international rivals such as Germany, Britain needed a friend in the world. Stampeders from that friend, the US, trekked into the Klondike

\footnotetext{
9 Paul Stevens and John T. Saywell, eds., Lord Minto's Canadian Papers: A Selection of the Public and Private Papers of the Fourth Earl of Minto, 1898-1904, vol. I (Toronto: Champlain Society, 1981), 50, 208 and 227.

10 "British Flag Hauled Down," San Francisco Chronicle, 29 June 1901; "Hauled Down the Union Jack," Democrat and Chronicle (Rochester, NY), 29 June 1901.

11 US President Ulysses S. Grant quoted on the topic in J.B. Moore, "The Alaska Boundary," North American Review CLXIX, no. 515 (October 1899), 501.

12 Stevens and Saywell, Lord Minto's Canadian Papers, 64.

13 Stevens and Saywell, Lord Minto's Canadian Papers, 65 and 71.

14 John R. Dos Passos, The Anglo-Saxon Century and the Unification of the English-Speaking People (New York: G.P. Putnam's Sons, 1903), 171-172.

15 Among the many sources one might consult are Norman Penlington, The Alaska Boundary Dispute: A Critical Reappraisal (New York: McGraw-Hill Ryerson, 1972); and John A. Munro, The Alaska Boundary Dispute (Toronto: Copp Clark, 1970).
} 
and then trekked out with most of the gold. Lord Minto noted in August 1900 that most of the Klondike's gold dust went to Seattle. ${ }^{16}$ Britain would fight to retain gold and other resources in South Africa, but it would not do so in the Klondike.

This was among the concessions Britain was willing to make for the sake of peace and international amity. Canada's governor general, who visited Dawson in the summer of 1900 , estimated that seventy percent of the city's population of 17,000 comprised "U.S. subjects of mixed races." ${ }^{17}$ In a secret letter to the British Colonial Secretary Joseph Chamberlain, Minto upped the percentage of Americans in Dawson to seventy-five. ${ }^{18}$ Whatever the actual number, it was possible to refer, as the Klondike Nugget did, to "the American occupation of the Klondike."19

\section{Certainty and US Shipping}

The Alaska-British Columbia boundary decision came after the Klondike gold rush's peak and made concretely legal what had been a de facto reality: US control of the sea routes to the gold fields of the far northwest. American control of the mouth of the Yukon River was never questioned. American control of the Lynn Canal had been at the heart of the border dispute but was never really threatened.

Few doubted Britain's global dominance on the world's seas and it is interesting that the nearest naval base to the North American Arctic and near Arctic - at Esquimalt, British Columbia - was British. Yet, in the far northwest, US shipping was clearly and unambiguously dominant. In terms of getting in and out of the Klondike for the large majority of stampeders and others, there was no question as to who was in charge. The United States' unquestioned control of the maritime routes to the gold fields helped to create an infrastructure of order and predictability in the gold rush regions. These were key psychological ingredients for the making of friendly, voluntary communal cooperation.

For one thing, ships and steamboats brought other pillars of security coastal protection and, more important, law enforcement. Having heard troubling stories about boomtown Skagway in Alaska, agents with the North American

16 Stevens and Saywell, Lord Minto's Canadian Papers, 391; Frederick Palmer, In the Klondike (New York: Charles Scribner's Sons, 1899), 200; and Lois Delano Kitchener, A Flag Over the North: The Story of the Northern Commercial Company (Seattle: Superior Publishing Company, 1954), 221.

17 Stevens and Saywell, Lord Minto's Canadian Papers, 388.

18 Stevens and Saywell, Lord Minto's Canadian Papers, 404.

19 Klondike Nugget editorial "The Eagle's Drooped Wings" clipping in US Consul James McCook file, series 11, vol. 1449, file 111 and vol. 19, file 27272, Yukon Archives. Charlotte Porsild estimates that the American-born (as differentiated from US residents born in other countries) made up about thirty percent of Dawson's gold rush population. See her Gamblers and Dreamers: Women, Men and Community in the Klondike (Vancouver: University of British Columbia Press, 1998), 71. Historian Morris Zaslow writes that between 1898 and 1900 Americans (or Americanized immigrants) probably comprised three-quarters of the estimated 40,000 people in the Yukon Territory. By 1901 the figure had fallen to about 32 percent and by 1911 to the still substantial minority of 22 percent. See Zaslow, "The Yukon: Northern Development in a Canadian-American Context" in Regionalism in the Canadian Community, 1867-1967, ed. Mason Wade (Toronto: University of Toronto Press, 1969), 196. 


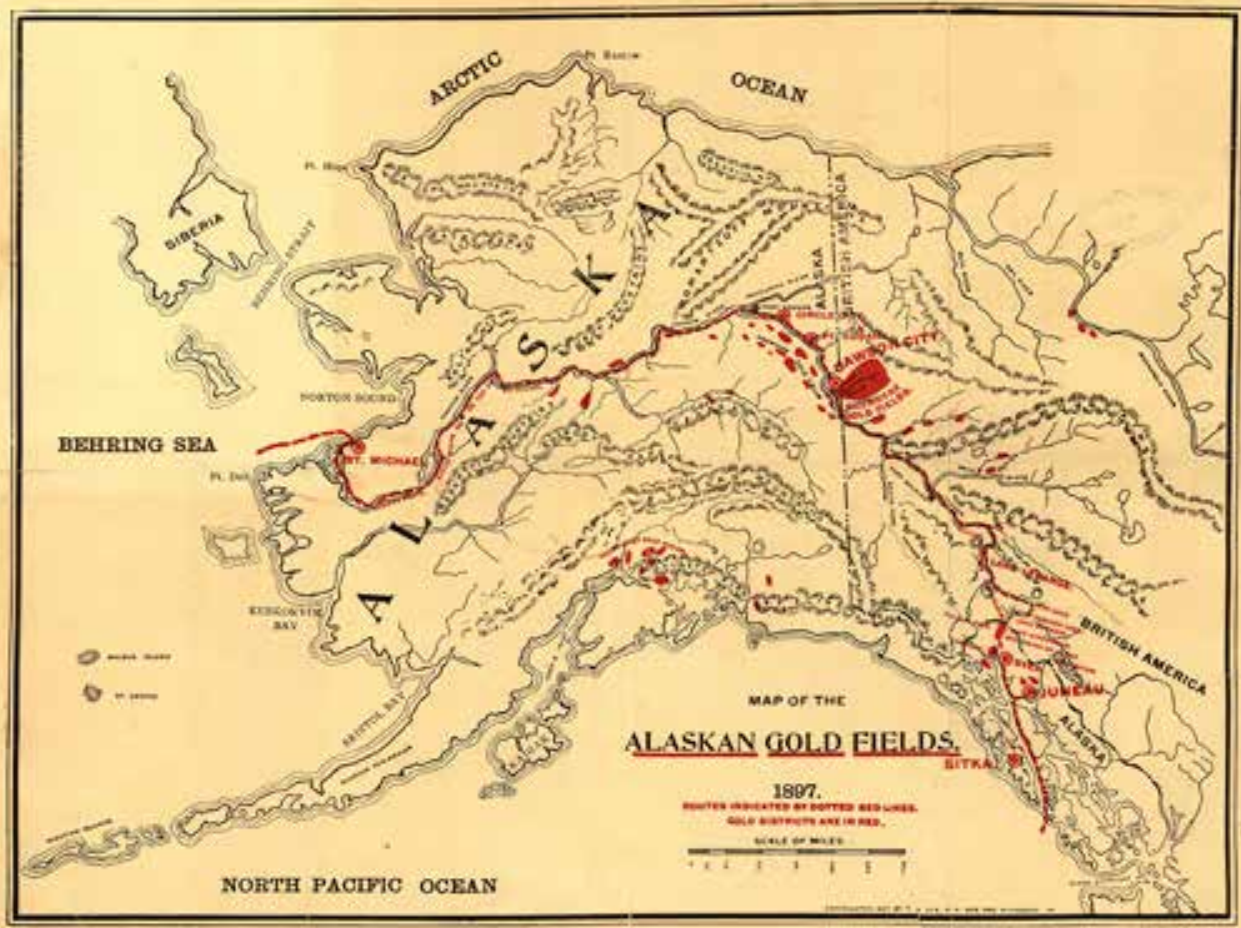

Image 1. T.S. Lee, Map of the Alaskan Gold Fields, 1897. (Library of Congress Geography and Map Division Washington, DC 20540-4650 dcu)

Transportation and Trading Company worried that a rapid influx of miners into the Yukon River region made it "probable that armed raiders will hold up steamers and loot the stores of their supplies." ${ }^{20}$ Captain P.H. Ray at Fort Yukon recommended that the US government send a gunboat to the river to preserve order. ${ }^{21}$ When incorrect reports went out that a Spanish privateer was in Alaskan waters seeking to loot Klondike gold, British ships from Esquimalt kept an eye on British Columbian ports while US ships covered the approaches to the gold fields. ${ }^{22}$

Ships also brought mail. A brief article in a British Columbian newspaper in November 1900 refers to the US gunboat Wheeling both in terms of security patrols in the Bering Sea and mail delivery. ${ }^{23}$ Memoirs, diaries, and letters suggest that mail came behind only food and winter warmth in importance to miners and others in the Arctic and near Arctic. Complaints about mail service are a constant

20 North American Transportation and Trading Company to Adjutant-General United States Army, 18 December 1897 in Narratives of Explorations in Alaska (Washington, DC: Government Printing Office, 1900), 539-540.

21 P.H. Ray to Adjutant-General United States Army, 27 August 1897 in Narratives of Explorations in Alaska, 521.

22 “Spanish Privateer," Ottawa Citizen, 27 July 1898.

23 "A Visit from the Wheeler [sic]," The Province (Vancouver), 28 November 1900. 
in the primary literature and what mail there was came overwhelmingly through US ports. ${ }^{24}$ "Postmaster General Gary has issued a formal order establishing an exchange of mails once a month between the post offices of Dyea, Alaska, and Dawson City, Can[ada]," the Chicago Chronicle reported in 1897. Mail steamers passed through Seattle, Juneau, and the Lynn Canal. ${ }^{25}$ Mail also went down the Yukon River, with Fort Yukon serving as a key mail posting and collection site. ${ }^{26}$

Fort Yukon, north of the Arctic Circle, was among the most important shipping sites of the gold rush era. Unimpressive to the eye, the fort's importance was often overlooked. In the spring of 1898, a gold seeker named Johann Jonsson wrote a letter, printed in the Winnipeg Tribune, describing Fort Yukon as "nothing" but a transportation company's storehouse, a missionary's home, and "a few log houses" inhabited by the Indigenous population. He was not impressed, though he added that there were "plenty of provisions here, the boats having discharged their cargoes here last fall that should have gone further up the river." ${ }^{27}$ Fort Yukon was unimportant except to the extent that it served as a storehouse for people passing through one of North America's most challenging regions. Put another way, Fort Yukon was unimportant except to the extent that it served as a storehouse for the "necessities of life." ${ }^{28}$ In other words, Fort Yukon was important.

In 1898, Army Lieutenant W.P. Richardson called Fort Yukon "a permanent transshipping point for the river business, where a large quantity of supplies may be stored." 29 Earlier, Captain Ray had called the site his "base of supplies." ${ }^{30}$ The Seattle Post-Intelligencer reported on the fort's vital role in the far northwest:

By reason of its location Fort Yukon is an objective point with steamers on the river. Last winter several steamers were caught there for the winter. When they cannot reach Dawson City by reason of low water they can generally get as far up as Fort Yukon, and from there supplies can be distributed in winter to the miners. If supplies were plentiful at Fort Yukon there would be no danger of starvation in the Klondike, as several times the journey has been made in winter between Fort Yukon and Dawson City. $^{31}$

Emily Craig Romig's diary of mid-1898 records multiple parties arriving at the fort on a single day to gather provisions. ${ }^{32}$ Around the same time, the Daily

\footnotetext{
24 Emily Craig Romig, A Pioneer Woman in Alaska (Caldwell, ID: Caxton Printers, 1948), 102.

25 "Mails for Alaska," Chicago Chronicle, 3 September 1897.

26 Romig, Pioneer Woman in Alaska, 102.

27 Winnipeg Tribune, 21 April 1898.

28 Arthur Treadwell Walden, A Dog-Puncher on the Yukon (New York: Houghton Mifflin Company, 1928), 33

29 W.P. Richardson, "Report of an Expedition into Alaska," in Narratives of Explorations in Alaska, 505.

30 P.H. Ray to Adjutant-General United States Army, 3 October 1897 in Narratives of Explorations in Alaska, 529.

31 “M’Donald Will Resign,” Seattle Post-Intelligencer, 9 October 1897.

32 Romig, Pioneer Woman in Alaska, 100.
} 
Klondike Nugget reported that many of the 105 passengers arriving in Dawson on the wooden sternwheel steamship Portius B. Weare had wintered at the fort. ${ }^{33}$ And several months later, when residents of the Dawson area feared starvation, they sought sustenance at Fort Yukon. ${ }^{34}$

Built as it was on a navigable river and linked to outside ports, Fort Yukon played an important role in tying the near Arctic to the global economy. ${ }^{35}$ Emily Craig Romig served as a cook and wrote of trade in potatoes and lemons. The availability of citrus fruit in the region was another important contribution of shipping that lay under American control. Indeed, if one did not know that Dawson City was in Canada, a review of shipping advertisements in the Daily Klondike Nugget might lead one to think it was within the United States. The name of the Seattle-Yukon Transportation Company could have suggested as much, while the Alaska Exploration Company promoted its ships as being "at St. Michael, direct for San Francisco." The steamship agents with Carol, Johnson and Company, based in Seattle, advertised "operating steamers from Puget." 36

A wide range of supplies arrived via US-controlled shipping. In the 5 July 1898 edition of the Nugget we find advertisements for wines, diaries, cigars, and ladies footwear, presumably all of which arrived from Pacific ports via the Lynn Canal or the Yukon River. Other notices that the steamers Merwin, Linda, Leon, and Arnold were soon departing St. Michael for San Francisco drove home the point of Klondikers' reliance on US shipping and maritime infrastructure.

It was a strange situation wherein one of the great gold-producing regions of the world rested under the British flag but access to it was largely controlled - and from the sea almost completely controlled - by a power whose leaders had only recently spoken of possible war with Britain.

Cultural affinity smoothed the way. For all the tensions that existed among Britons, Anglo-Canadians, and Americans, the commonalities were greater. In this era of rapprochement, Britain's Colonial Secretary Joseph Chamberlain spoke of Americans as people who "speak our language" and as relatives whose laws, literature, and human sentiments were "the same as ours." ${ }^{37}$ In this spirit, the British strategist G.S. Clarke envisioned a "naval league" between the two Englishspeaking nations whose joint economic power would be felt globally. Together the countries would "dictate ... peace throughout the sea highways of the world." Five years before Hawaii's annexation by the United States, he had declared that the islands "must become American soil." British commercial interests, Clark wrote, would benefit from American order in the western hemisphere and the Pacific.

\footnotetext{
33 “The Weare Arrives," Daily Klondike Nugget, 16 June 1898.

34 P.H. Ray to Adjutant-General United States Army, October 26, 1897, in Narratives of Explorations in Alaska, 535-537, 549, 501.

35 A point also emphasized in Kathryn Morse, The Nature of Gold: An Environmental History of the Klondike Gold Rush (Seattle and London: University of Washington Press, 2003), 139.

36 Advertisements, Daily Klondike Nugget, 23 June 1898.

37 Quoted in Palmer, In the Klondyke, 47.
} 
In turn, British harbors sprinkled around the globe were "ready to become resting, coaling, and refitting stations for United States ships." 38 The spirit of such thoughts traveled the rivers and trails of the far northwest.

Difficult as life in the far northwest could be, without the benefits of US shipping it would have been impossible for all but a few of the hardiest gold rush stampeders. Even in the depths of winter, when the canned goods previously imported were dwindling, one could hold in mind the promise of spring and ships and steamboats of life's necessities and niceties. This knowledge, this certainty, reduced stress and promoted cooperation.

To be sure, ships and steamboats faced difficulties and schedules went unkept. There were, as one newspaper headline said, "Steamboats with a Hoodoo." These experienced troubles

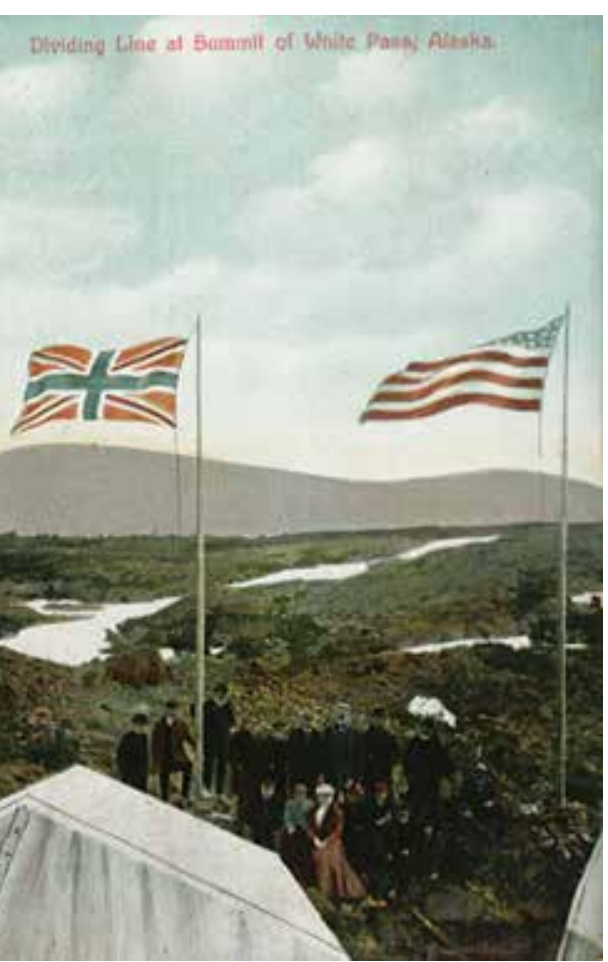

Image 2. Postcard depicting the White Pass Summit, c. 1907. (Courtesy of the author) such as insufficient fuel, a lack of competent captains, tortuous channels, and hidden sandbars "at almost every turn." ${ }^{39}$ But these challenges were met and people in the far northwest could be sure that vessels would continue to come and go.

\section{Certainty and Canadian Law Enforcement}

The sense of certainty that came with US control of sea access to the gold fields was a pole of security around which a culture of cooperation could be built. Another pole was the almost universally-praised work of Canada's North-West Mounted Police - at least amongst European stampeders and settlers. ${ }^{40}$

\footnotetext{
38 G.S. Clarke, “A Naval Union with Great Britain,” North American Review (March 1894): 362363.

39 Dawson Weekly News, 29 March 1901. Also see Morse, Nature of Gold, 80.

40 Editor's Note: It should be noted that the relationship between the Yukon's Indigenous Peoples and the police during these years was more complex. While the Mounties served as a "buffer" and provided some protection from an encroaching non-Indigenous population, they also imposed British-Canadian law, altered traditional legal norms and systems, and attempted to control elements of Indigenous life. Historian Ken Coates has argued that Indigenous Peoples in the Yukon "accepted the police's leadership, both because they respected the force and because they feared imprisonment." So, while the police offered a pole of certainty and security for European settlers during this period, the NWMP sometimes meant the opposite for the Yukon's Indigenous Peoples. Ken Coates, Best Left as Indians: Native-White Relations in the Yukon Territory, 1840-1973 (Montreal \& Kingston:
} 
In a ranking of significance, shipping was more important for the simple reason that Canadian authorities relied on US-controlled access to the Klondike. Queen Victoria's own representative in Canada, Governor General Minto, had to come and go through Skagway. And while NWMP sergeant M.H.E. Hayne wrote that no ship as overloaded and burdened as the one he sailed on from Seattle would have been allowed to leave an English port, he nevertheless relied on US ocean-going transport, not only for the delivery of personnel but, like everyone else, for food, life amenities, mail, and outside news. ${ }^{41}$

Tourist lore is full of gold rush tales of crooks, gunfights, and swinging saloons. This applied especially to early Skagway, particularly among men who had yet to endure the rigors of wintertime cold and summertime mosquitoes. Once these had spent a day or two on the Chilkoot Trail or White Pass, a new reality set in. Finding themselves facing an uncertain or unexpectedly difficult journey to the gold fields, many abruptly returned to the certainty of a ship's passage back home. Meantime, those who pressed on knew that when they did wish to return to the outside, there would be ships on the Lynn Canal to take them home. Moving northeast from the Alaskan panhandle and into British territory, then, stampeders could look back to a system of secure shipping under US control. Looking forward, they could anticipate competent Canadian policing.

Memoirs from the gold rush era almost uniformly praise Canada's law enforcement. "Too much cannot be said of the personnel of the Northwest Mounted Police," wrote Frederick Palmer, for they punished criminals with the "commendable promptness of British justice" and prevented unprepared stampeders from entering Canadian territory, where a lack of resources would make travelers a burden to others. ${ }^{42}$

Women's memoirs and diaries, especially, sound the theme of the Mounties' positive impact. Anne DeGraf wrote that the Mounties were "always on the lookout for travelers" and provided security for women trekking to and from Dawson. One officer saved her from drowning. There was some crime in Dawson's first years, she wrote, "although it is remarkable the way the Canadian Mounted Police kept order." She remembered the Mounties as cordial, dutiful, courageous, and persevering. When "once assigned to a case, they never let up until they find their man, whether the search takes them to South Africa or any other part of the globe." 43 Martha Black recalled Mounties escorting miners bearing large amounts of gold, regardless of nationality. Everybody, she wrote, obeyed the Mounties. ${ }^{44}$

May Sullivan was generally negative about political life in the Yukon Territory,

\footnotetext{
McGill-Queen's University Press, 1993), 182. See also William R. Morrison, Showing the Flag: The Mounted Police and Canadian Sovereignty in the North, 1894-1925 (Vancouver: University of British Columbia Press, 1985), 142-161.

${ }_{41}$ M.H.E. Hayne, Pioneers of the Klondyke (London: Marston and Co, 1987), 6.

42 Palmer, In the Klondyke, 10, 191-192, 207-208.

43 Palmer, In the Klondyke, 66, 67, 70, 103, 104.

44 Martha Louise Black, My Ninety Years: Her Story from the Dawson Gold Fields to the Halls of Parliament (Anchorage: Alaska Northwest Books, 1976), 29, 56, 64, 71, 76.
} 
but she recounted the work of the mounted police as "the most commendable thing about Canadian Government." Thanks to them, she wrote, stealing was almost unheard of and petty theft was all but non-existent. "Mounted police in their brown uniforms and soldiers in their red coats are everywhere seen in and around Dawson, and they practice methods, which, to the uninitiated, make them see very nearly omnipresent." 45

Mounties gave provisions to needy people and their animals. "I promptly went up to one of the officers, told him we were half famished and begged a meal," writes E. Hazard Wells. "He pointed to a tent nearby.... We proceeded to it and secured much-needed refreshment." 46 An American army officer at Fort Yukon thought that US authorities should organize "a system of mounted police, similar to that in [Canada's] Northwest Territory." ${ }^{47}$

All was not positive. May Sullivan describes a ship en route to Dawson full of drunken women and men, including a few "Canadian police in red coats" who were "fully as rollicking" as any, and, along with "the steamer's captain and purser, arm in arm with a big, burly Canadian official," were "as drunk as bad liquor could well make them." 48 American brothers in the Klondike described a Mounty as susceptible to bribery. ${ }^{49}$ But such comments are rare. ${ }^{50}$

To the secure post of American shipping, then, we add the secure post of Canadian policing. And these posts of security served as psychological scaffolding upon which sojourners in the far northwest could build a culture of cooperation.

\section{Maslow's "Hierarchy of Needs" in the gold rush context}

To be sure, a common dominant culture made cooperation easier. The general culture of the Klondike was substantially shaped by values shared by people who spoke English as a primary language and identified with the political and cultural traditions of England. US-British cooperation was already at work geopolitically and at the time of the Klondike and Nome gold rushes prominent voices were calling for greater unity among Anglo-Saxon peoples. The American writer John Dos Passos, for example, argued that "the consolidation of Canada into our republic [was] an indispensable condition to the establishment of a complete and permanent brotherhood between the Anglo-Saxon people."51 The extent to which miners and others in the far northwest were familiar with these ideas is not known. The dearth

\footnotetext{
45 May Kellogg Sullivan, A Woman Went to Alaska (Boston: James H. Earle \& Co, 1903), 38.

46 E. Hazard Wells, Magnificence and Misery: A Firsthand Account of the 1897 Klondike Gold Rush (New York: Doubleday, 1984), 182, 184.

47 W.P. Richardson to Major T.H. Barry, 29 August 1897 in Narratives of Explorations in Alaska, 522.

48 Sullivan, $A$ Woman, 24-25.

49 Charles J. Roehr, ed., Klondike Gold Rush Letters: Along the Trail of '98 from Dyea, Alaska, to Dawson, Yukon Territory (New York: Vantage Press, 1976), 19.

50 Still the best study of the Mounted Police in the Far Northwest is Morrison, Showing the Flag: The Mounted Police and Canadian Sovereignty in the North, 1894-1925.

51 Dos Passos, The Anglo-Saxon Century and the Unification of the English-Speaking People, 159.
} 


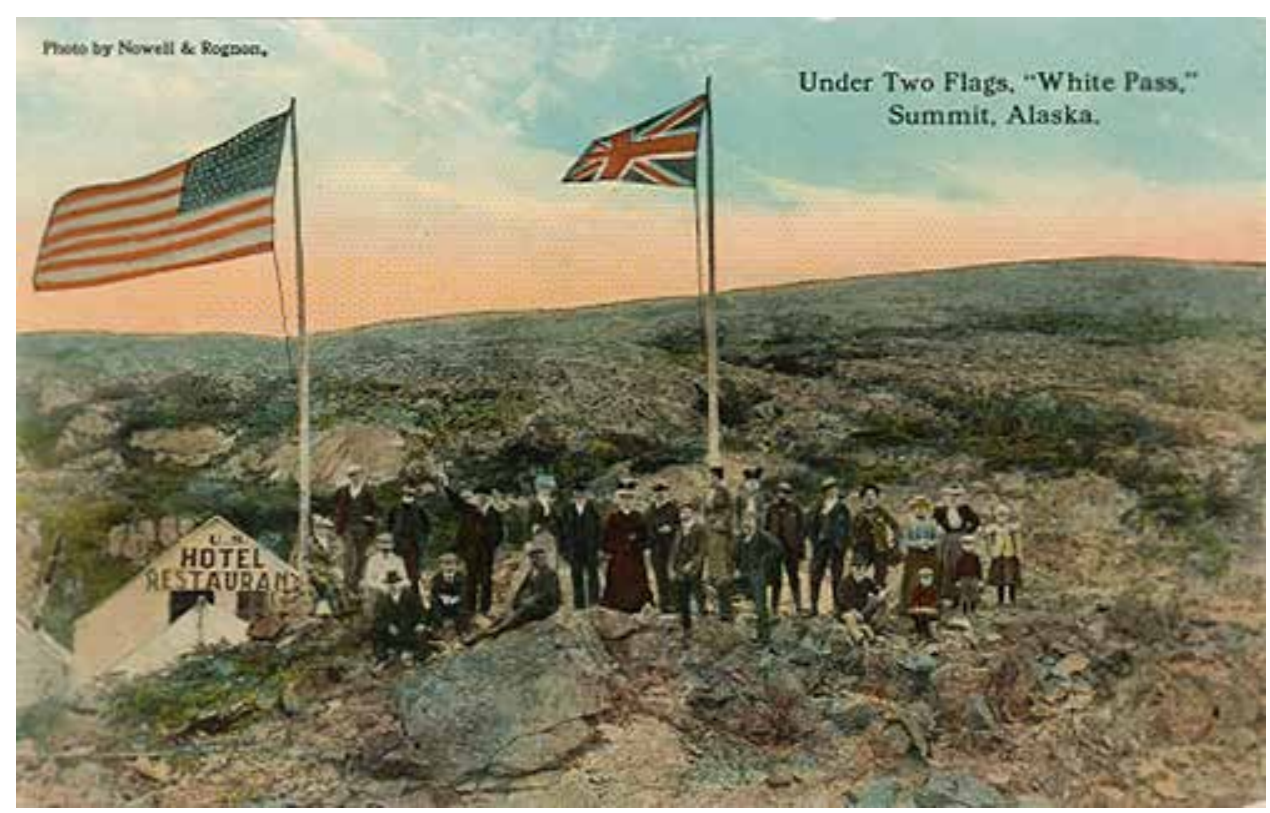

Image 3. Postcard, "Under Two Flags, 'White Pass Summit,' Alaska," c. 1907. (Courtesy of the author)

of commentary on them in sources apart from newspaper editorials in Dawson newspapers does not suggest that they had a great impact in the region..$^{52}$

It is true, as myriad memoirists note, that gold rush society in the far northwest was multilingual and multi-cultural. ${ }^{53}$ Yet it is also true that Anglo-American culture was dominant. The work of Shakespeare, for example, was a cultural staple. Anna DeGraf wrote of some miners reading Shakespeare while others danced. ${ }^{54}$ Elizabeth Robins' Alaska diary includes reflections on Coriolanus. ${ }^{55}$ Miners'

52 For a different view, see Adam Arenson, "Anglo-Saxonism in the Yukon: The Klondike Nugget and American-British Relations in the 'Two Wests'," Pacific Historical Review 76, no. 3 (August 2007): 373-404; and Edward P. Kohn, This Kindred People: Canadian-American Relations and the Anglo-Saxon Idea, 1895-1903 (Montreal \& Kingston: McGill-Queen's University Press, 2004). Influenced by Kohn, Arenson argues that in Dawson City, in the years 1898-1901, British and American identities effectively merged into an Anglo-Saxon identity and these two constituent groups cheered on one another in their imperial endeavors. For "a brief moment," he writes, "as racial rhetoric was honed and national bonds merged, the Yukon joined the Philippines, South Africa, and China as a key battlefield in the global fight for an imagined Anglo-Saxonism" (403). Arenson roots his thesis primarily in editorial comments published in the Klondike Nugget, and there certainly are words in that newspaper that called for closer cooperation between the English-speaking peoples. But the present writer cannot recall reading any other relevant primary material that gives clear preference to an Anglo-Saxon, as opposed to a British, Canadian, or American identity. Perhaps such sources exist, but it seems unlikely that they could justify the claim, for example, that Dawsonites were enthused about "Anglo-Saxonist Empire, from Dawson to Manila" (380).

53 See, among many examples, James Wickersham's reference to the "polyglot mob" that filled Dawson's streets in the gold rush days, in Terrence Cole, ed., Old Yukon: Tales, Trails, and Trials (Fairbanks: University of Alaska Press, 2009), 14.

54 Anna DeGraf, Pioneering on the Yukon, 1892-1917 (Hamden, CT: Archon Books, 1992), 84.

55 Victoria Moessner and Joanne E. Gates, Alaska-Klondike Diary, 1900 (Fairbanks: University of 
letters and conversation employed phrases from As You Like It and Hamlet. ${ }^{56}$ One memoirist compared "blackmailing" customs agents in the Klondike to the Tempest's Shylock. ${ }^{57}$ The Nome writer E.S. Harrison quoted Julius Caesar and Hamlet when musing on the possibility of some kind of providential order at work in the universe. ${ }^{58}$

Certainly, a common culture shared by most who went to the gold regions facilitated cooperation. But the work of Shakespeare - an ornament of life, like peace and neighborliness - can be enjoyed only if basic needs are met. Such, anyway, is the basic premise of one of the most widely known and acknowledged psychological theories, Abraham Maslow's "hierarchy of needs," which observes that a starving man will not be interested in poetry, that a woman living with constant high levels of insecurity will not have an open disposition to strangers, and that if a person is enjoying the works of Shakespeare, then we can assume that his or her basic human needs have been met. Community feeling, enjoyment of art, mutual kindliness, and respect, in other words, will "all be waved aside as fripperies" by a hungry person "since they fail to fill the stomach."

As Maslow observes, physiological needs - food, water, and protection from the elements - are most basic. Next come safety needs - rudimentary protection. Then come relational needs - the giving and receiving of care and attention. Thirdly come esteem needs - "self-respect, or self-esteem, and ... the esteem of others." And, finally, comes what Maslow calls "self-actualization": an individual exercising his or her personal gifts and interests; an "individual doing what he is fitted for." 60 So when a scholar of the Klondike gold rush correctly writes that labor in the far northwest gave Klondikers "a better, broader sense of themselves and their capabilities," and when she quotes Klondikers expressing pride in what they have learned to do amidst the rigors of the Yukon territory, then we know that basic needs were met. The starving and the greatly insecure do not care, say, about high-quality small boat building. ${ }^{61}$ For the desperate, any old boat will do.

US-controlled shipping made available most of the food Klondikers and Alaskans ate. Thus, a most basic need was met. Then came the law enforcement officials on gunboats and steamships - and another basic need (security) was met. When the basic needs of food (and other rudimentary amenities) and security are supplied, then people will "hunger for affectionate relations with people in general." 62 And this is mostly what we find in the gold rush regions, not only in the sites most associated with shipping (St. Michael, Fort Yukon, post-frenzy

\footnotetext{
Alaska Press, 1999), 137.

56 Roehr, Klondike Gold Rush Letters, 22 and 51; and Harry Graham, Across Canada to the Klondyke (Toronto: Methuan Publications, 1984), 121.

57 Luella Day, The Tragedy of the Klondike (New York: n.p., 1906), 31.

58 E.S. Harrison, Nome and Seward Peninsula, 253, 380, and 390.

59 A.H. Maslow, “A Theory of Human Motivation,” Psychological Review (1943): 374.

60 Maslow, "A Theory of Human Motivation," 376-381.

${ }_{61}$ Morse, The Nature of Gold, 123.

62 Maslow, "A Theory of Human Motivation," 381.
} 
Skagway, and Nome) or with Canadian police work (Dawson City) but in the spaces in between. These posts, this infrastructure, of certainty - US shipping and Canadian law enforcement - served as foundations upon which a broader culture of trust was built.

It may be, as one Klondike memoirist says, "that garlic cynicism ... has its natural abiding-place in the unkempt beards of hardened frontiersmen. ${ }^{963}$ Yet these same men also spoke of "a law, though an unwritten one" to which most assented. Its essence, described and referenced in numerous memoirs, was the Golden Rule: treat others as you would wish to be treated. If you were not using your cabin, the moral law usually called for it to be left unlocked so others could use it. If you had more food than you needed at a given moment and another had less, the law called for you to share. In whatever circumstance, the law called on you to foster trust because, at some point, you would likely need someone's help, just as the person now in front of you needed yours. This was not idealism so much as enlightened self-interest. I help you because at some point I may need you to help me. Those who did not abide by this law were "ordered out of the country." ${ }^{44}$ Adherence to this law required abstract, forward thinking - the ability to imagine oneself in the future, needy and benefitting from a culture of cooperation that had been made possible by the prior satisfaction of basic human needs.

In the Council City area, not far from Nome, there was little formal law enforcement. The culture of cooperation guided behavior. Lanier McKee writes of a certain Pete Wilson "who came forward and told us that we might camp upon his neighboring lot until the fall [without charge], and who further said that he would trust us not to set up a title to the ground adverse to his." McKee continues: "This is just one instance of the many kind and generous acts of which such men are capable; and it was the beginning of a neighborly association with this hearty old miner, who contributed in many ways toward our agreeable sojourn at Council City." 65

The most striking evidence for the culture of cooperation existing at the time of the Klondike and Nome rushes are the memoirs of women who traveled in the region, sometimes alone. To be sure, there were problems: the Klondike Nugget reported on a Japanese girl, about fifteen years old, who had been forced into prostitution by her father, a man of "low character and complicated disposition"; 66 Josephine Knowles wrote of a woman who lived in a state of continual fear of her sociopathic husband; ${ }^{67}$ and Henry Munn writes of seeing Nellie Lamore with

\footnotetext{
63 Palmer, In the Klondyke, 81.

${ }^{64}$ William Stanley, A Mile of Gold: Strange Adventures in the Yukon (Chicago: Laird and Lee, 1898), 63.

65 Lanier McKee, The Land of Nome (New York: Grafton Press, 1902), 50, 78-79.

66 Ian McDonald and Betty O'Keefe, The Klondike's "Dear Little Nugget" (Victoria: Horsdal and Schubart, 1996), 31.

67 Josephine Knowles, Gold Rush in the Klondike: A Woman's Journey in 1898-99 (Fresno, CA: Quill Driver Books, 2016), 51-58.
} 
a black eye bestowed on her by her "boy" who had a "mean temper at times." But as with reports of violence between miners, these cases stand out for their differentiation from the norm. (Harry De Windt claimed never to have seen a fistfight during his sojourn in the far northwest. $)^{69}$

In keeping with the customs of the day, women were usually treated with respect and deference. Sources tell of women given favored sitting spots in wagons; of having free entry through a toll-gate over the Snake River Bridge at Nome, while men had to pay; and of receiving help in various tasks from men - in exchange for the smile of a young woman or the motherly presence of an older one. ${ }^{70}$ Josephine Knowles wrote of men in a hotel surrendering their beds and sleeping on the floor upon the arrival of a woman. ${ }^{71}$ "Wherever we went, and whatever the hour, we met with no incivility," another woman remembered.

Hats were lifted, and men rested a moment upon their shovels to look after us as we passed, while frequently some rough miner swallowed a lump in his throat or wiped a tear, as he thought of his wife, daughter or sweetheart far away. We were the only women in the mines for miles around, but felt no fear whatever, and indeed we were as safe there as at home, and there was no occasion for anxiety. ${ }^{72}$

Joe Ladue, often called the founder of Dawson City, complained that no man could get justice in a miners meeting - a sort of impromptu civilian court - if he were in a dispute with a woman who, by virtue of her gender, was considered morally superior. ${ }^{73}$ In the country, along the creeks, between settlements, and in parts of town a little distant from saloons, a civil culture prevailed. In these places, when women were near, men guarded their tongues from uttering words "their own mothers would ... blush to hear." 74

Gold rush story-telling has generally failed to make an important distinction. The wildness and rollicking of legend had mostly to do with the behavior of men (and some women) away from the rigors of making a life in a northern context. Elizabeth Robins wrote of a Mrs. List, aboard the ship Teresa, as a "delicate, very pretty person who had suffered even more than I from the habits of some of our fellow-passengers" whose "spitting and hawking ... went on uninterruptedly." Yet Mrs. List seemed to know that things would change when northern reality set in. She persisted in her plan to open a restaurant in Nome, complete with silver utensils, fine table linen, and a trained cook. ${ }^{75}$ And where May Sullivan wrote

68 Henry Toke Munn, Prairie Trails and Arctic By-Ways (London: Hurst and Blackett, 1932), 112.

69 Harry De Windt, Through the Gold-Fields of Alaska (New York: Harper Brothers, 1898), 145.

70 Romig, Pioneer Woman in Alaska, 39; May Kellogg Sullivan, A Woman Who Went to the Klondike (Boston: James H. Earle, 1903), 105 and 127.

71 Knowles, Gold Rush in the Klondike, 27 and 75.

72 Sullivan, A Woman Who Went to the Klondike, 129.

73 J. Lincoln Steffens, "Life in the Klondike Gold Fields: Personal Observations of the Founder of Dawson," McClure's Magazine (September 1897): 965.

74 Sullivan, A Woman Who Went to the Klondike, 133.

75 Elizabeth Robins, Raymond and I (London: Hogarth Press, 1956), 130. 
of stampeders aboard ship en route to the Seward Peninsula from Dawson as desperadoes and reckless men, rollicking with "dance house girls" and bent on getting gold any way they could, she remembered them in the field as kind and courteous. ${ }^{76}$ Soapy Smith, the Skagway gang leader, con man, and killer is the subject of so many books, lectures, and web pages precisely because he stands out from the norm - because he was so unrepresentative. He never climbed the White Pass and he was off the scene (killed in a gunfight) by July 1898.

\section{Cooperation and International Community Development}

Most of the human capital in the Klondike during the gold rush came from Americans and others who arrived after first immigrating to the United States. American energy did its work within the context of British-Canadian law. This was not always smooth and there were many complaints. On one occasion, petitioners to the Canadian government, encouraged by Dawson's American majority, spoke of "widespread indignation in the Yukon District because of the extravagant taxation imposed on miners by recent regulations." "77 But the system generally worked.

Though outnumbered, Britons and Canadians played key roles in the development of the region. May Sullivan wrote with fondness of a "pleasant mannered young Englishman" who represented rich interests in the Klondike and was returning to London. She described another Englishman as young and handsome and dressed in the "triggest of dude toggery." On her second trip to Alaska in the spring of 1900, she was accompanied by what she called an English, perhaps meaning Canadian, family. ${ }^{78}$

May Wynne Lamb, a teacher in Akiak, Alaska, writes with equal fondness of Jack Heron, a Canadian, and her school's handyman, Percy Goodair, an Englishman who carried himself "with all the dignity of an English lord" until he left Alaska to fight with British forces in the First World War. ${ }^{79}$ And while E.S. Harrison's encyclopedic Nome and Seward Peninsula (1905) makes the Ontario native Albert Boyd into an honorary American, Boyd led "the first surveying party of the Canadian Pacific Railroad into the Rocky Mountains" and chose to be married in British Columbia. ${ }^{80}$

A Canadian named Lewis Tanner established an important lumber business in Nome. ${ }^{81}$ Canadian-born A.C. Stewart was vice president and general manager of the Golden Dawn Mining Company, "which owns some of the most valuable mining property on [the] Seward Peninsula." David Gilchrist was born in Ontario and

\footnotetext{
76 Sullivan, A Woman Who Went to the Klondike, 43, 63-64, and 71.

77 "Appeal of the Yukon Miners to the Dominion of Canada" (Ottawa: Mortimer Co., 1898), 93.

78 Sullivan, A Woman Who Went to the Klondike, 52 and 73.

79 May Wynne Lamb, Life in Alaska: The Reminiscences of a Kansas Woman, 1916-1919, ed. Dorothy Wynne Zimmerman (Lincoln: University of Nebraska Press, 1988), 64-65.

80 E.S. Harrison, Nome and Seward Peninsula: History, Description, Biographies and Stories (Seattle: n.p., 1905 ), 229-232.

81 Harrison, Nome and Seward Peninsula: History, Description, Biographies and Stories, 253.
} 
worked in Winnipeg and Vancouver before arriving in Juneau on 3 July 1892, and "[s]ince that date he has been an Alaskan." In Nome, Gilchrist operated a freighting business and served as an elected city councilman. Canadian native Albert Browne established Alaska's biggest producer of hydraulic pipe and fixtures. ${ }^{82}$

Canada marked Alaska in other ways. James Wickersham, a federal judge and future Alaska governor, wrote that around the year 1900 Canadian currency comprised "practically all" the money used along the American Yukon. "All the United States gold and currency coming into Dawson was retained by the Dawson banks for their own remittances to the States," he wrote, "and in lieu of American money they handed out worn Canadian bills to all persons coming down the river into Alaska." This prevented gold owned by Americans from entering Alaska, and it made the judge's collection of fines, licenses, and fees difficult. "It took five years to get enough United States gold coin and currency into our district to enable us to carry on the public business with United States money." 83 A similar problem marked Nome's early days. ${ }^{84}$

Then there was the "world-class engineering accomplishment" of the White Pass and Yukon Railway connecting Skagway and White Horse. It exemplified international effort, as its construction involved "British financing, American engineering, and Canadian contracting." ${ }^{85}$ And Dawson served as a kind of model in a near Arctic settlement. In December 1904, James Wickersham moved his judicial headquarters from Eagle to Fairbanks, which he called "the Dawson of the central Yukon basin." $" 86$

Such cross-border cooperation did not spring from nowhere. A common, dominant Anglo-American culture paved the way. But cultural goods can be capitalized to a great degree only when basic needs - food and security - are met. These needs were met, pervasively, by American shipping and regionally by Canadian policing.

\section{Conclusion}

Discussions linking Alaska, and especially its far north, to international relations have been taking place since the gold rushes of the late $1890 \mathrm{~s} .{ }^{87}$ The

\footnotetext{
82 Harrison, Nome and Seward Peninsula: History, Description, Biographies and Stories, 284, $310-$ $311,321$.

83 James Wickersham, Old Yukon: Tales, Trails, and Trials, ed. Terrence Cole (Fairbanks: University of Alaska Press, 2009), 22.

${ }_{84}$ Kitchener, Flag Over the North, 247.

85 Roy Minter, The White Pass: Gateway to the Klondike (Fairbanks: University of Alaska Press, 1987), 13.

$86 \quad$ Wickersham, Old Yukon, 267.

87 See, for example, Preston Jones, Empire's Edge: American Society in Nome, Alaska, 18981934 (Fairbanks: University of Alaska Press, 2007), 47-49. The city of Anchorage was founded with geopolitical concerns in mind. See Preston Jones, "Context" in City for Empire: An Anchorage History, 1914-1941 (Fairbanks: University of Alaska Press, 2010). The past's relevance to the present and future is indicated in Christopher Sands, "Canada's cold front: Lessons of the Alaska boundary
} 
early twenty-first century assumption that peace in the Arctic will require close cooperation between Canada and the US calls to mind the Klondike and Nome gold rush era, when Americans rushed into the Yukon Territory and Canadians helped to build Alaska. Canadians and Americans, together, created an orderly world in the far northwest.

The culture of cooperation that existed in the Arctic and near Arctic was built atop an infrastructure of certainty and stability. Principal questions about transportation, resource supply, and security were answered by Americans, Britons, and Canadians working together.

When we look beyond the dazzle of gold rush tales about saloon madness and gun fights, we find stampeders assisting one another, sacrificing for one another, lending a hand. This was enlightened self-interest. But enlightened self-interest implies a degree of moral reflection and forethought. Such qualities are unlikely if basic needs go unmet. Security is a basic need, which Canadian law enforcement provided in the Yukon Territory. The spirit of that enforcement - the moral habits it encouraged - crossed the border.

Another basic need was confidence that if a traveler in the far northwest could get to a certain port or navigational site, then he or she could go home. The sending and reception of mail, frustrating as the slowness of this could be, was highly important if not quite basic. Obviously, food that could not be extracted from the region itself or purchased from inhabitants was essential.

Confidence about such things translated into reduced levels of stress. Reduced stress made for heightened cooperation. US shipping and Canadian law enforcement together made this possible. Of the two, the more foundational was shipping.

Preston Jones is a Professor of History at John Brown University, Arkansas, United States.(Contact: pjones@jbu.edu) 